\title{
ARTIFICIAL INTELLIGENCE AND COPYRIGHT
}

\section{Paulo Vítor Souza*}

Summary: 1 . Introduction; 2 . Artificial Intelligence; 3 . Copyright; 4 . Possible solutions to the issue; 4.1 Artificial Intelligence and Copyright Owner; 4.2 The user, programmer, or Artificial Intelligence Company as Copyright Owner; 4.3 Immediate Entry into the Public Domain; 5. Conclusion.

Sumário: 1. Introdução; 2. Inteligência Artificial; 3. Direito de Autor; 4. Possíveis soluções para o problema; 4.1 Inteligência Artificial e Direito de Autor; $4.2 \mathrm{O}$ usuário, programador ou empresa desenvolvedora da Inteligência Artificial como proprietária do Direito de Autor; 4.3 Entrada imediata no Domínio Público; 5. Conclusão.

\begin{abstract}
Artificial Intelligence is one of the emerging technologies with the most potential nowadays. The scale of use is increasingly broad, and many companies are involved in developing this technology with significant investments. In this sense, intellectual property issues have been raised in several legal systems, with different approaches. Knowing who owns the copyright of works produced by an AI is crucial as it will directly impact the development of this technology. Furthermore, it is paramount for fully autonomous AI, as there is no human intervention in these. Another path would be creating a robotic legal personality, which raises ethical and legal issues that will take time to overcome.
\end{abstract}

Resumo: A Inteligência Artificial é uma das tecnologias emergentes com mais potencial nos dias atuais. A escala de utilização é cada vez mais abrangente e há muitas Empresas envolvidas no desenvolvimento desta tecnologia, com investimentos avultados. Neste sentido, questões relativas a quem detém a propriedade intelectual têm sido levantadas em diversos sistemas jurídicos, com diferentes abordagens. Saber quem é possuidor do direito de autor das obras produzidas por uma IA é importante, uma vez que terá um impacto direto no desenvolvimento desta

\footnotetext{
* Jurista formado pela Faculdade de Direito da Universidade Lusófona (Lisboa). Mestrando em Direito e Tecnologia na Nova School of Law (Lisboa). Investigador no Centro de Investigação e Desenvolvimento WhatNext.Law. Encarregado de Proteção de Dados na Satcom International AG.

Graduated from the Law School of Lusófona University (Lisbon). Master's candidate in Law and Technology at Nova School of Law (Lisbon). Researcher at WhatNext.Law Research and Development Center. Data Protection Officer at Satcom International AG.
} 


\section{PAULO VÍTOR SOUZA}

tecnologia. Na verdade, é primordial quando se trata de IA totalmente autónomas, uma vez que não há nestas a intervenção humana. Outro caminho seria a criação de uma personalidade jurídica robótica, o que levanta questões éticas e legais que aparentemente demorarão a ser superadas.

KEYwords: Artificial Intelligence; Copyright; Digital Law; Legal Personality; Law and New Technologies.

Palavras-Chaves: Inteligência Artificial; Direito de autor; Direito Digital; Personalidade Jurídica; Direito e Novas Tecnologias. 


\section{Introduction}

This work will address the issue of Copyright and Artificial Intelligence. Such a study would have been a work of science fiction some years ago, but nowadays the evolution of AI makes many scholars start to develop studies on the subject, mainly in the field of intellectual property rights. In addition to Copyright, AI can also impact patent law, trademarks and design.

The first chapter will deal with the definition and classification of AI. The second will address Copyright's definition and the differences between some systems, such as European and American systems. Then, an overview will be given of the current legislation within Portuguese and European scope so as to define the next developments in this area. Finally, some possible solutions will be demonstrated, with their pros and cons.

\section{Artificial Intelligence}

If the emergence of computers brought some difficulties to Copyright, the current development of Artificial Intelligence is the great challenge of this branch of intellectual property law. Computer algorithms and learning machines have become a new source of creativity and, as such, they require a look into copyright law.

In this sense, a definition of AI should be sought. This definition is not easy because AI covers an extensive field and does not have a single definition ${ }^{1}$. However, in general, it is understood that AI must possess a sign of human intelligence ${ }^{2}$. It must also comprise the capacity to understand natural language and the possibility to evaluate and decide on

\footnotetext{
1 Cezar Junior Souza and Claudio Alcides Jacoski, "Propriedade intelectual para criações de inteligência artificial", Brazilian Journal of Development 6, n. 5 (2020): 32344-56, https://doi. org/10.34117/bjdv6n5-615.

2 Raymond Kurzweil, "What Is Artificial Intelligence Anyway? As the Techniques of Computing Grow More Sophisticated, Machines Are Beginning to Appear Intelligent - but Can They Actually Think?", American Scientist 73, no. 3 (26 December 1985): 258-64, http://www.jstor.org/ stable/27853237.
} 
moral grounds $s^{3}$. Therefore, definitions of AI have a direct connection with intellectual abilities, the ability to understand, learn and make autonomous decisions, regardless of the developer or user ${ }^{4}$. This "intelligence" is clearly not organic, but artificial. This way, it is a software system capable of imitate human ways of thinking with the help of a computer or other devices 5 .

When we talk about AI, we think about the possibility of robots performing, in an intelligent way, every day and professional tasks, which were once performed exclusively by human beings ${ }^{6}$. In this sense, nowadays it is already possible for cars to be automatically driven, pictures to be painted using $\mathrm{AI}^{7}$, the creation of music and even journalistic articles resorting to $\mathrm{AI}^{8}$. As can be seen, $\mathrm{AI}$ is endowed with creativity since the input produces an unexpected result in the output, which means that AI uses the data entered to create something new, and it is impossible to accurately know how it came to a certain conclusion. That has been called the black box of AI, i.e., transforming the data into an unexpected output ${ }^{9}$. In computational creativity, for an AI to be considered creative, it needs to look for solutions that are not replications of previous solutions, and there is also the need to look for acceptable solutions for the task proposed ${ }^{10}$.

3 Mark Mckamey, "Legal Technology: Artificial Intelligence and the Future of Law Practice", Appeal: Review of Current Law and Law Reform 22 (2017): 45-58, https://papers.ssrn.com/sol3/ papers.cfm?abstract_id $=3014408$.

4 Souza and Jacoski, "Propriedade Intelectual Para Criações de Inteligência Artificial”.

5 Paulius Čerka, Jurgita Grigiené, and Gintare Sirbikyté, "Liability for Damages Caused by Artificial Intelligence", Computer Law \& Security Review 31, n. ${ }^{\circ} 3$ (2015): 376-89, https://doi.org/https://doi. org/10.1016/j.clsr.2015.03.008.

6 Fernanda Borghetti Cantali, "Inteligência artificial e direito de autor: tecnologia disruptiva exigindo reconfiguração de categorias jurídicas”, Revista de Direito, Inovação, Propriedade Intelectual e Concorrência 4, no. 2 (2018): 1, https://doi.org/10.26668/indexlawjournals/2526-0014/2018. v4i2.4667.

7 See at: https://www.nextrembrandt.com

8 See at: https://www.theguardian.com/commentisfree/2020/sep/08/robot-wrote-this-articlegpt-3

9 Yavar Bathaee, "The Artificial Intelligence Black Box and the Failure of Intent and Causation", Harvard Journal of Law \& Technology 2, n. 4 (2011): 31-40, https://www.theverge.com/.

10 Jani Mccutcheon, "The Vanishing Author in Computer-Generated Works: A Critical Analysis of Recent Australian Case Law", Melbourne University Law Review 9, n. 3 (2013): 189-91, http:// classic.austlii.edu.au/au/journals/MelbULawRw/2013/4.html. 


\section{ARTIFICIAL INTELLIGENCY AND COPYRIGHT}

There are two types of AI, according to scholars. One is more superficial, used as an additional tool in human creation. The other is complex AI, which does not depend on the human being and is, therefore, autonomous. Autonomy implies that the work produced by AIs must act alone, without the constant input of a human ${ }^{11}$. This second type of AI is capable of learning on its own, through what is called Machine Learning, that is, through experience and new data, not being the result of creative decisions by programmers, but of the program itself ${ }^{12}$. From Machine Learning, another programming modality has developed, Deep Learning, which uses artificial neural networks, simplified simulations of how biological neurons behave and extracts rules and patterns from specific data sets ${ }^{13}$.

In this sense, the first-rate AI does not pose a problem concerning Copyright, since they are only the human creator's additional tools. Those of the second type, on the other hand, give rise to this discussion in the field of Copyright, precisely because they possess autonomy and a certain degree of creativity.

Finally, although AI possesses a certain level of creativity, it should be borne in mind that it is still not comparable to human creativity. That is because it will not imagine concepts and categories with which it has never had contact. There is also no evidence it has characteristic traits of human creativity, such as intentionality, desires and beliefs ${ }^{14}$. In conclusion, it is impossible to think like human beings, always being limited to the data imputed to them.

11 Margaret A. Boden, The Creative Mind: Myths and Mechanisms: Second Edition, 2003, https:// doi.org/10.4324/9780203508527.

12 Andrés Guadamuz, "Do Androids Dream of Electric Copyright? Comparative Analysis of Originality in Artificial Intelligence Generated Works", Intellectual Property 2uarterly, 2017 (2) 2018, no. Ch D (2017): 20, https://ssrn.com/abstract $=2981304$.

13 T.C, "How machine learning works", The Economist, May $14^{\text {th }}, 2015$, https://www.economist. com/the-economist-explains/2015/05/13/how-machine-learning-works

14 Pedro de Perdigão Lana, "A questão da autoria em obras produzidas por Inteligência Artificial", Instituto Jurídico - Universidade de Coimbra (2019), https://papers.ssrn.com/sol3/papers. cfm?abstract_id=3508834. 


\section{Copyright}

Copyright is an integral part of intellectual property rights. It is a legal right granted to the creator of original work, enabling exclusive rights for its use and distribution. Generally, two essential features are required for the grant of a copyright: first, the work must be in a tangible form; and second, it must be original ${ }^{15}$.

The legal protection of creative works produced with AI systems is undoubtedly one of the most complex and intriguing issues faced by lawyers in the 21 st century. In the historical context of Copyright, we can present two original institutes: Copyright in Common Law countries and Droit d'auteur in countries with a Roman-Germanic tradition ${ }^{16}$. In the Anglo-Saxon legal system, the utilitarian nature of property prevails, while in the French influence the author's figure and the dualistic moral and patrimonial character of the guardianship are prevalent ${ }^{17}$. However, legislation - both based on Copyright and the Droit d'auteur - is silent in what concerns Copyright's issues in works with non-human authorship. Nevertheless, a broader reading of the texts suggests that the notion of authorship that guarantees legal protection only comprises human beings ${ }^{18}$.

The majority positions of Portuguese doctrine reinforce the idea of creativity and of a work that goes beyond the purely technical ${ }^{19}$. Firstly, AI technology itself incorporated into the computer program is a protected work

15 Mihai Lupu, "Artificial Intelligence and Intellectual Property", World Patent Information 53, no. 1 (2018): A1-3, https://doi.org/10.1016/j.wpi.2018.06.001.

16 Ana Clara Sampaio Guedes do Amaral, "A Inteligência Artificial e o Direito do Autor: Uma análise da possibilidade de tutela jurídica para criaçôes intelectuais produzidas com sistemas de inteligência artificial", Res Severa Verum Gaudium, 2020, www.seer.ufrgs.br/ressevera.

17 Roberto Correa de Mello, "O Copyright não cabe na ordem jurídica do Brasil", Conjur, 2013, https://www.conjur.com.br/2013-mai-29/roberto-mello-copyright-nao-cabe-ordem-juridica-brasil.

18 Eleonora Rosati, "The Monkey Selfie Case and the Concept of Authorship: An EU Perspective", Journal of Intellectual Property Law \& Practice 12, n. ${ }^{\circ} 2$ (1 December 2017): 973-77, https://doi. org/10.1093/jiplp/jpx199.

19 Marcos Wachowicz, Alexandre Libório Dias Pereira, and Pedro de Perdigão Lana, Novos Direitos Intelectuais: Estudos Luso-Brasileiros, GEDAI/UFPR, 2019, https://www.mendeley. com/catalogue/088e9337-8a44-3c97-990d-00814a7eefe2/?utm_source=desktop\&utm_ medium $=1.19 .4 \& u t m \_c a m p a i g n=o p e n \_c a t a l o g \& u s e r D o c u m e n t I d=\% 7 B e 399 c 605-88 \mathrm{c} 7-455 \mathrm{a}-$ a9e7-84b7d4804388\%7D. 


\section{ARTIFICIAL INTELLIGENCY AND COPYRIGHT}

because of the protection of computer programs and databases in Articles 2 of the Berne Convention ${ }^{20}$, together with Articles 4 and 5 of the WIPO ${ }^{21}$ Copyright Convention, in addition to Article 36 of the $\mathrm{CDADC}^{22}$ and Decree-Law ${ }^{23} 122 / 2000^{24}$. However, the discussion's complexity rests with $\mathrm{AI}$ as the subject of protection, and not as the object. The International Treaties in force do not sign a definition of an author, but their text generates the interpretative presumption that they are human ${ }^{25}$. The Berne Convention reinforces this idea by establishing moral rights and differentiating between ideas and expression ${ }^{26}$. In the European Union, there are several Directives which imply the idea that the author must be human, even if not in a direct way ${ }^{27}$. Nevertheless, these directives have moved the Droit d'auteur into Copyright norms, generally for economic reasons. In this sense, the creative author's centrality has been diminishing, and situations that seem to distort fundamental principles have been allowed to appear whenever there are "works without author"28.

The European Court of Justice has been called upon to give its views on the author's definition in the Infopaq directives and has stated that only human

20 Berne Convention for the Protection of Literary and Artistic Works: https://www.wipo.int/ treaties/en/ip/berne/

21 Convention Establishing the World Intellectual Property Organization: https://www.wipo.int/ treaties/en/convention/

22 Portuguese Code of Copyright and Related Rights: https://dre.pt/web/guest/legislacaoconsolidada/-/lc/34475475/view

23 Decree-law is what is called an Act in Portugal.

24 Transposes into national law Directive 96/9/EC of the European Parliament and of the Council of 11 March 1996 on the legal protection of databases: https://dre.pt/web/guest/pesquisa/-/ search $/ 300833 /$ details $/$ maximised?perPage $=50 \& q=$ Lei + n. ${ }^{\circ}+10 \% 2 \mathrm{~F} 97$

25 Lana, "A questão da autoria...."

26 Jane C. Ginsburg, "People Not Machines: Authorship and What It Means in the Berne Convention", IIC - International Review of Intellectual Property and Competition Law 49, no. 2 (2018): 131-35, https://doi.org/10.1007/s40319-018-0670-x.

27 Directive on computer programs (Directive 2009/24/EC), on databases (Directive 96/9/EC) and rental, lending and certain rights related to Copyright (Directive 2006/115/EC).

28 José de Oliveira Ascensão, "Direito de autor sem autor e sem obra", in Stvdia Ivridica - Boletim da Faculdade de Direito - Universidade de Coimbra (Coimbra: Universidade de Coimbra, 2008), 87 108, http://www.gedai.com.br/wp-content/uploads/2019/02/ASCENSĀO-J.-Oliveira.-Direitode-Autor-sem-Autor-e-Sem-Obra-2.pdf. 
creation is protected ${ }^{29}$. However, it has extended the criterion of subjective originality, requiring a low level of creative demand. In Painer ${ }^{30}$ and Football Dataco $^{31}$ cases, it added the idea of "personal touch" to the work and the author's ability to make free and creative choices, which for the time being hinders the possibility of machine copyright ${ }^{32}$.

In Common Law systems we find the most straightforward answer to the possibility of robotic authorship of works created by artificial intelligence. On the one hand, in the American system the Copyright Office denies requests for registration if a human being was not the work creator $^{33}$. On the other hand, in the United Kingdom's legal system there is the granting, without further reservation, of the work generated by computer for the human involved in its programming, through an exception to creativity criterion. In this sense, the Copyright of computergenerated works belongs to the person who made the necessary arrangements for their creation, which is generally the programmer, with moral rights being expressly excluded and a shorterperiod of time being set for the property rights ${ }^{34} 35$.

Nevertheless, the UK solution is not free from criticism, as it does not clearly define who made the necessary arrangements for the creation of the work. Is it the user, the programmer, the investor? In this sense, there is no reason to import this solution into the Portuguese legal system since it may come up against "authorless copyright" situations ${ }^{36}$.

29 Case C-05/08 Infopaq International, ecli:eu:c:2009:465.

30 Case C-145/10 Painer, ecli:eu:c:2011:798.

31 Case C-604/10 Football Dataco, ecli:eu:c:2012:115.

32 Lana, "A questão da autoria"; Wachowicz, Pereira, and Lana, Novos Direitos Intelectuais.

33 Points 306 and 313.2 of the Copyright Office Compendium of Practice.

34 Section 9(3) of the CDPA. Further on, section 178 of the CDPA defines a computer-generated work as something "generated by computer in circumstances such that there is no human author of the work".

35 Guadamuz, "Do Androids Dream of Electric Copyright? Comparative Analysis of Originality in Artificial Intelligence Generated Works"; Catherine Colston, "Principles of Intellectual Property Law”, Principles of Intellectual Property Law, 1999, https://doi.org/10.4324/9781843142812; Lana, "A questão da autoria".

36 José de Oliveira Ascensão, Direito Civil, Direito de Autor e Direitos Conexos, 1. ${ }^{a}$ ed., (Coimbra: Coimbra Editora, 2012). 
In the national legal system, it has been understood that the author can only be a natural person and that even in cases where this natural person is left, as in the case of Legal Entities, it should be reminded that, after all, behind Legal Entities are natural persons, without whom they would not exist. In this sense, if it is possible to identify a direct link of the person's intention behind the machine, this person must be the holder of the protection. Nevertheless, if it is not possible to determine who this person is, the work created would be beyond Copyright $^{37}$.

\section{Possible solutions to the issue}

As there is not yet a single uniform guideline on who would own the Copyright in a piece of work created by an autonomous artificial intelligence, an analysis of all reasonable copyright assignments is required ${ }^{38}$. Works generated by AI were excluded from eligibility for copyright protection. In fact, the copyright system would be seen as a tool to encourage and foster human creativity's dignity at the expense of mechanical creativity. If copyright protection was granted to AI-generated works, the copyright system would tend to be regarded as an instrument to favor the availability of the largest number of creative works and the equal value of human creativity and machinery ${ }^{39}$. In this sense, the following section will briefly discuss possible ways of addressing the issue within Copyright.

37 Oliveria Ascensão, Direito Civil, Direito de Autor; Alexandre Dias Pereira, Direitos de Autor e Liberdade de Informação, (Almedina, 2008); Lana, "A questão da autoria".

38 Victor M Palace, "What If Artificial Intelligence Wrote This: Artificial Intelligence and Copyright Law”, Florida Law Review 71, n. 1 (2019): 217, https://heinonline.org/HOL/ License.

39 (WIPO) World Intellectual Property Organization, "WIPO Conversation on IP and AI", Revised Issues Paper on IP and AI, no. WIPO/IP/AI/2/20/1 Rev (2020): 10, https://www.wipo.int/ meetings/en/doc_details.jsp?doc_id=407578. 


\section{1. ARTificial INTELLIGENCE AS A COPYRIGHT OWNER}

The first way is to attribute the Copyright to AI itself. That would require amending the definition of author. Consequently, the creation of a robotic personality would also be necessary. Bearing this in mind, in 2017 the European Parliament adopted a resolution ${ }^{40}$ with recommendations to the Commission on civil law rules in robotics. The resolution admits the possibility that, in the long term, AI may overcome human intellectual capabilities and recognize that some aspects of robotics may require specific consideration, such as a decoupling of the requirement to protect the concept of human authorship ${ }^{41}$.

Some authors argue that AI should be given a special personality type, such as that possessed by Companies. Nevertheless, as has been stated before, firms always have the human element behind them, which will not happen with evolved and autonomous AI. Therefore, the two situations differ entirely from each other ${ }^{42}$.

Therefore, the current picture does not accommodate non-human authors' idea, since Copyright's main characteristic is the incentive to creation, offering exclusive creator rights. Thus, the financial incentive makes no sense for $\mathrm{AI}^{43}$.

\section{2. THE USER, PROGRAMMER OR ARTIFICIAL INTELLIGENCE COMPANY AS A COPYRIGHT OWNER}

The second approach is to assign Copyright ownership to the user, programmer or artificial intelligence company, expanding the doctrine of "work to hire". Under the Copyright Act, ownership of Copyright initially

40 See: https://www.europarl.europa.eu/doceo/document/A-8-2017-0005_EN.html

41 Souza and Jacoski, "Propriedade intelectual para criações de inteligência artificial"; Palace, "What If Artificial Intelligence Wrote This".

42 Ana Ramalho, "Will Robots Rule the (Artistic) World? A Proposed Model for the Legal Status of Creations by Artificial Intelligence Systems”, SSRN Electronic Journal, no. July (2018): 1-20, https://doi.org/10.2139/ssrn.2987757.

43 Palace, "What If Artificial Intelligence Wrote This". 
belongs to the author. Nevertheless, in the case of a "work made for hire", ownership is transferred to the "employer". Currently, work is a "work made for hire" either when an employee creates it or when, among other features, it is commissioned. This argument seeks to add a third condition, which includes works created by artificial intelligence ${ }^{44}$. That is the case of the UK and also Ireland. In this case, the definition of whom would be the employer must be achieved on a case-by-case basis.

There are several advantages of this solution: it would reward all those defined as "employees" and it would also encourage them to reveal how much contribution was given by $\mathrm{AI}$ in the creative process; there would be a greater incentive to the AI market ${ }^{45}$.

Nevertheless, on the other hand, the main problems would be, for example, the benefit of creation given to people who have actually not contributed to it. There would also be the risk of rewarding programmers twice: one through software protection and another through Copyright. Furthermore, there could also be a large concentration of these technologies in the hands of only a few software developers, which could generate an enormous inequality of access to them ${ }^{46}$. Finally, it seems that this theory can only apply to certain types of works and that a machine does not fit properly either into the duality of commissioner-commissioner or employee-employer ${ }^{47}$.

\section{3. IMMEDIATE ENTRY INTO THE PUBLIC DOMAIN}

The public domain model is currently the main form of copyright treatment for AI derived products. Since machines produce the creations, there is no Copyright, precisely because of direct human participation. In this sense, the public domain of AI works allows human beings to remain an integral part of the creative fields. However, stating that there is no direct protection

44 Annemarie Bridy, "Coding Creativity: Copyright and the Artificially Intelligent Author", Stanford Technology Law Review, 2012; Palace, "What If Artificial Intelligence Wrote This".

45 Palace, "What If Artificial Intelligence Wrote This".

46 Ibidem.

47 Lana, "A questão da autoria". 
does not mean that there can be no investment protection for developing new AI technologies ${ }^{48}$.

The public domain seems to have been the EU's path with the Database Directive and appears to be the best option within the framework of the Portuguese National Legal System.

\section{Conclusion}

In light of all this, it seems that, as stated above, the best model is in the public domain. The possibility of granting legal personality to machines seems, at present, in the light of existing legislation, very distant. The United Kingdom model, as we have seen, has positive points, but it may in certain situations give rise to the creation of works without an author when it is not possible to identify a human behind the creation, which will become increasingly common with the evolution of AI.

In this sense, in the development of creative AI, it is possible to defend the elaboration of a related or sui generis right related to the dissemination of works, such as those foreseen in Article 39 of the CDADC ${ }^{49}$. Based on Related Rights, this model would have the peculiarity of protecting the investment made by Companies in AI while not distorting the classical principles of Copyright.

48 Lana, "A questão da autoria"; Ramalho, "Will Robots Rule the (Artistic) World?"; Palace, "What If Artificial Intelligence Wrote This"; Wachowicz, Pereira, and Lana, Novos Direitos Intelectuais; Luca Schirru, "Direito autoral e Inteligência Artificial: Autoria e titularidade nos produtos da IA", no. July (2020): 353, https://doi.org/10.13140/RG.2.2.22509.41445.

49 Wachowicz, Pereira, and Lana, Novos Direitos Intelectuais; Lana, "A questão da autoria”. 